\title{
A Completeness Framework for Critical Success Factors of ERP Implementation Projects: A Stakeholders' Perspective
}

\author{
Rekha Gupta ${ }^{1}$,S. Kazim Naqvi ${ }^{2}$ \\ FTK- Centre of Information Technology,Jamia Millia Islamia,New Delhi,India \\ ${ }^{1}$ rekhagupta@lbsim.ac.in \\ ${ }^{2}$ sknaqvi@jmi.ac.in
}

\begin{abstract}
The complex and integrated nature of Enterprise Resourse Planning (ERP) system is often coupled with time constraints and substantial financial commitments that inevitably make its implementation to be a highly risky undertaking. Reviews of the existing literature on the subject suggest that Critical Success Factors (CSFs) have been studied by researchers for risk aversion in ERP implementations. The review studies have often provided different listing of CSFs as per their research settings and scope. ERP projects necessitate organization wide transformation making stakeholders involvement and participation crucial for the success guarantee of the ERP project. Critical Success Factors related to stakeholders are often found in the understated position in spite of the prime contribution and difference they make to ERP implementation success story. The paper focusses on importance of identifying stakeholders' CSFs for studying, monitoring and controlling purposes. It further attempts to provide a consolidated list of stakeholders CSFs along with proper categorization.
\end{abstract}

\section{Indexing terms/Keywords}

Enterprise Resource Planning, Critical Success Factors, Completeness, Stakeholders' Critical Success Factors,

\section{Academic Discipline And Sub-Disciplines}

Information systems, Business Information Systems

\section{SUBJECT CLASSIFICATION}

Enterprise Resource Planning

\section{TYPE (METHOD/APPROACH)}

Review Survey, Quantitative Study

\section{Council for Innovative Research}

Peer Review Research Publishing System

Journal: International Journal of Management \& Information Technology

Vol. 5, No. 2

editor@cirworld.com

www.cirworld.com, member.cirworld.com 


\section{INTRODUCTION}

\section{CRITICAL SUCCESS FACTORs(CSFs) APPROACH TO ERP IMPLEMENTATION}

CSFs models have been applied to general project management problems, manufacturing system implementation, and reengineering (Holland, Light \& Gibson, 1999). Rockart (1979) developed the Critical Success Factors concept as a way of identifying general managers' information needs, and defined CSFs as "those few critical areas where things must go right for the business to flourish". The importance of CSFs as a means of identifying and prioritizing business needs and technical systems has been recognized in several IT planning approaches (Byrce \& Byrce, 1987; Buyukozkan, Kahraman \& Ruan, 2004; Buyukozkan ,Ertay, Kahraman \& Ruan, 2004; Botta-Genoulaz ,Millet \& Grabot, 2005). The CSFs based frameworks are expected to guide managers in the development of an implementation strategy and help them make decisions by identifying the role and influence of individual factors on each other and on the project outcome (Holland and Light 1999; Ngai, Law \& Wat, 2007).

The approach has also been widely adapted to address ERP implementation issues (Bingi, Sharma \& Godla, 1999;Cantu, 1999; Holland and Light, 1999; Holland ,Light \& Gibson, 1999; Esteves \& Pastor, 2000; Bernroider \& Koch, 2001; Nah Lau \& Kuang, 2001 ;Somers \& Nelson, 2001; Zhang ,Lee, Zhang \& Banerjee, 2002; Umble, Haft \& Umble, 2003; Buyukozkan et al., 2004a; Botta-Genoulaz et al., 2005 ; Marnewick \& Labuschabne, 2005; Motwani et al., 2005 ; Sun ,Yazdani \& Overend, 2005; Sumner, 2006; Ngai et al., 2007). The CSFs for ERP implementation bring a concept that helps an organization identify the critical issues that affect the process of implementation. These factors are believed to have a critical impact over the ERP implementation as they will ensure a successful ERP implementation (Fok et al, 2009; Ngai et al., 2007) if carried out effectively.

\section{STAKEHOLDERS' ROLE IN ERP PROJECT IMPLEMENTATION}

ERP implementations are over and above the technical artefacts that are installed in the enterprise. ERP systems necessitate organizational transformation that affects the enterprise holistically. Apart from the difficulties that are synonymous with such changes, it is important to keep in mind that organizations are social structures made up of stakeholders whose interests converge or diverge depending on roles, values or situations. This complicates the matter even further. Undoubtedly, stakeholders consent and participation is important in view of the massive changes required. When stakeholders comprehend the proposed long-term benefits, related to an ERP implementation, acceptances of transient set-backs are more easily consented.

There are various kinds of stakeholders involved in the ERP project lifecycle. Broadly they could be classified as internal and external stakeholders'.

\begin{tabular}{|c|c|}
\hline Types of Stakeholders & Role \\
\hline \multicolumn{2}{|l|}{ Internal } \\
\hline Top Management & Strategic ; Instrumental in driving ERP Project \\
\hline Project Management Team & Executive; Instrumental in implementing ERP in organization \\
\hline Project Development Team & Development: Instrumental in developing in-house ERP(in-house ERP) \\
\hline ERP users & Operational; Instrumental in using ERP \\
\hline ERP Support Team & Support; Instrumental in providing support services for ERP Project (in-house ERP) \\
\hline \multicolumn{2}{|l|}{ External } \\
\hline ERP Vendor & Partner; Instrumental in offering ERP product ,support and services \\
\hline ERP Consultant & Partner; Instrumental in mediating between Vendor and implementing organization \\
\hline
\end{tabular}

Figure 1: ERP Stakeholders'

Akkermans \& Helden (2002) also identified that the presence and attitudes of stakeholders were the root causes driving performance of the acknowledged core processes. In their particular context, it emerged that simultaneous and mutually reinforcing changes in the presence and attitudes of stakeholders enabled a change in the project directional success.

Chetcuti (2008) noted that more than half of the issues in the ERP implementation project failures are of the non- technical nature. Poor change Management, lack of top management support and inability to align business process have been cited as main reasons for implementation failure. 
Shah, Khan \& Bokhari (2011) explored the impediments towards successful implementation faced by public organization where the development and implementation of ERP system was outsourced to a vendor. The findings showed lack of user involvement, lack of top management support, lack of vendors experience and support, and lack of change management as impediments of ERP successful implementation. Moreover, turnover of ERP developers team members and transfer/posting or retirement from service of top management of beneficiary organization were also found as impediments towards successful implementation of ERP system. The factors mentioned caused the project to be cost over- run, behind schedule and not according to user requirements.

\section{RESEARCH QUESTIONS}

The CSFs studies at a glance appear to be a perfect set of factors available for guidance and monitoring of ERP projects from the ERP implementers' perspective. In almost all the studies, about half of the listed CSFs are associated with the stakeholders'. Still several questions remained unanswered for CSFs in general and for stakeholders' CSFs in particular.

\section{- $\quad$ Lack of completeness of reported CSFs}

Different studies have provided a different listing of CSFs as per their research setting, scope and phase wise coverage of ERP project. Further, only a few studies attempted to list CSFs through all phases of ERP project. Further, all the CSFs listed in a study may/may-not find their place in other studies as per the researchers' understanding. Hence, no visible set could be obtained as an effective and comprehensive CSFs list from the studies.

\section{- Lack of categorization of CSFs}

The CSFs studies have been completely lacking in the proper categorization of related CSFs. For example, the CSF such as Formulation of steering committee, Having a Business plan and Vision, ERP strategy, Top Management support, Commitment, Formulation of an implementation team with Defined roles and responsibilities and Sustained Support are all related to Top Management. These CSFs could be bought in one prominent CSF, Top Management related CSF.

\section{- Subjectivity in interpretation and scope of CSFs}

The interpretation of the CSFs had been highly subjective and dependent on the researchers understanding. Few studies did not even provide the basic interpretation. Further, the scope and coverage of the CSFs varied across the studies with no fixed boundaries and limitations. . For example, studies have often talked of effective project management with a solid project champion backing without concentrating on supporting essential CSFs of interdepartmental co-ordination, cooperation, time and scope of implementation.

\section{- Biasness towards few CSFs}

Studies have been inconsistent or lack comprehensive completeness in reporting their listed CSFs. Although, apparently the Top Management and Client related CSFs are most widely reported in the CSFs studies. The other relevant CSFs, for example, consultant CSFs have been sporadically covered. Few CSF have not been able to make it to the review studies but have become relevant in context of ERP implementation as of date. For example, Defining the scope of work for the vendor and consultant, review of vendor and consultant work plays a very crucial role throughout the ERP project implementation but have been conveniently missed in most of the studies.

\section{RESEARCH METHODLOGY}

In order to address the above issues, a field study was conducted with 30 Indian enterprises in Delhi-NCR region in the year 2012. The companies were selected by size to include large and medium. Data was collected through an experience survey using a questionnaire. The questionnaire solicited opinions from the ERP Experts, Consultants, Vendors and implementers for determining the impact of Critical Success Factors (CSFs) on success of ERP software system in organizations. The respondents included senior level information system executives who had at least 10 years of experience in implementing and consulting ERP projects. The responses were secured by personal interviews and by email.

The success factors used in the questionnaire are based on research study publication in 1999 by Cantu, $R(1999)$, with modifications based on the noted drawbacks and inadequacies of previously cited CSFs. Each Prominent Critical Success Factor was further categorized into sub-factors for deeper understanding of their individual contribution to the impact made. A glossary of the technical terms used in the questionnaire was appended at the end of the document explaining the interpretation of terms as desired.

Respondents were asked to identify the overall degree of importance of each CSF in the overall ERP Project implementation stage using a 5-point likert scale ranging from not important to critical. 
The initial mailing was done to 50 senior level executives out of whom 30 responses were collected. The development of the questionnaire had the objective of gathering information directly from people involved in ERP implementation process and to have a complete listing of CSFs as relevant, appropriate and apt in today's contextual environment.

\section{RESULTS AND DISCUSSION}

\subsection{Completeness and Phase wise Categorization of the CSFs}

The comprehensive complete CSF model based on the survey conducted by us comprises of 5 prominent top level CSFs. The CSFs are of 5 major types ranging from Top Management/Organizational Support, Client, Vendor, Consultant and Project Management. The detailed sub-factors under each CSF have been discussed further. The comprehensive categorization would eventually be beneficial to implementers to serve as a basic guideline to focus on stakeholders' CSFs while massive investment with enterprise wide ERP implementation is done.

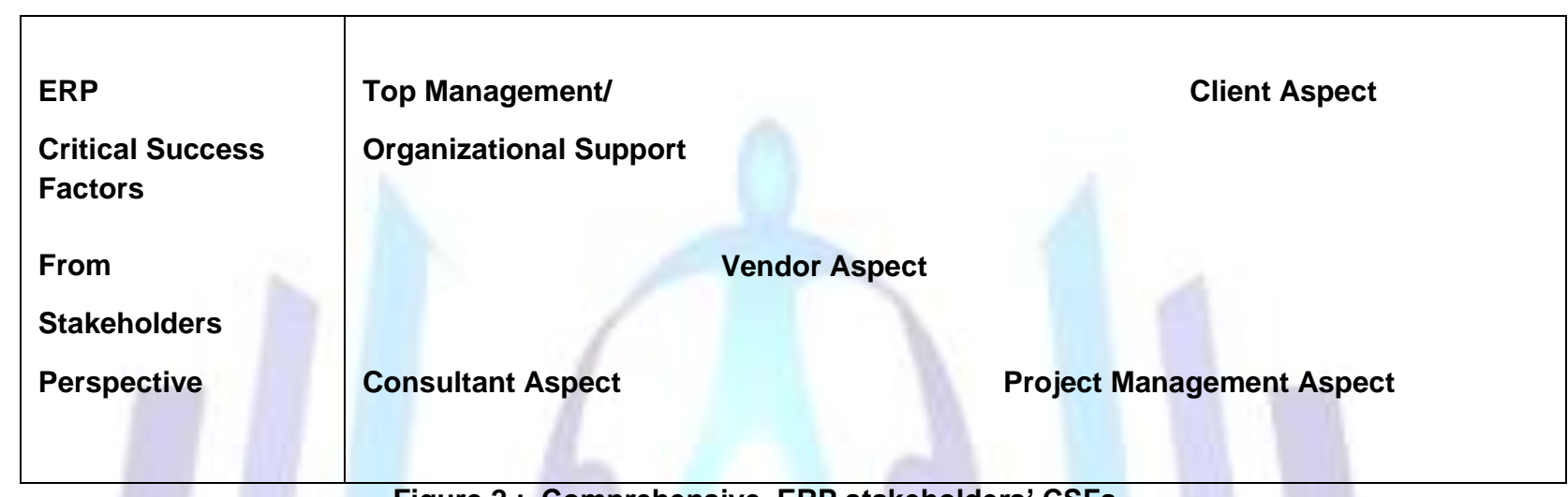

Figure 2: Comprehensive ERP stakeholders' CSFs

Below we present a detailed account of findings from the survey. We focus on each of the prominent CSFs separately and present an insight into its related CSFs which were placed under it.

\subsubsection{Top Management/Organizational Support}

Implementing an ERP system is often a matter of repositioning the company and transforming its business practices (Bingi, 1999). Top Management / Organization Support had emerged as an important CSF in almost all of the studies ( Bingi, 1999; Somers \& Nelson, 2001; Sumner, 2005; Garcia-Sanchez \& Bernal, 2007; etc). The foremost thing is formulation of a steering committee with senior executive representation from all business areas affected by ERP implementation (Sumner, 2005; Plant \& Wilcocks,2005). This CSF also encompasses a series of related sub-factors such as formulating Mission and Vision statement, setting clear goals and objectives of ERP project for the organization, selecting a project team with defined roles and responsibilities along with involvement, commitment and sustained support. Having a measurable attribute in terms of clear goals and objective makes analyzing the level of success easier and helps in making employees more motivated as they would know how their work will be evaluated. (Welti, 1999).

Our survey findings indicate that this CSF should take into account a long term vision and mission support for the ERP implementation along with the commitment and sustainable support in wake of significant top level personnel changes, changed market and financial position and changed strategic planning. The ERP mission and vision statement should be formulated stating the importance of ERP system in corporate mission, objectives and strategy. This should also be broadcasted to the entire company before actual implementation of ERP starts.

The top management pre-implementation work includes listing definite project goals and objectives, project team composition with well-defined roles, powers and responsibilities The top management should lead the project linking the objectives of the project with the company strategic priorities. By getting involved, top management as one of the most important stakeholders can ascertain that their expectations are clearly communicated. Further, they should act as champions for the implementation at all times and motivate employees from all levels to get involved (Mendel, 1999). Companies intending to implement an ERP system must be willing to delicate some of their best employees to the project for a successful implementation. Internal resources on the project should exhibit the ability to understand the overall needs of the company and should play an important role in guiding the project efforts in the right direction. Companies should consider comprehensive guidelines while selecting internal resources for the project. Lack of proper understanding of the project needs and the inability to provide leadership and guidance to the project by the company's internal resources is a major reason for the failure of ERP project. Further, keen involvement, strong leadership and commitment of the management are required during all phases and stages of ERP implementation. Further, survey showed that sustained 
support of the top management is another key requirement during all phases of the ERP project and especially in wake of top management personal changes.

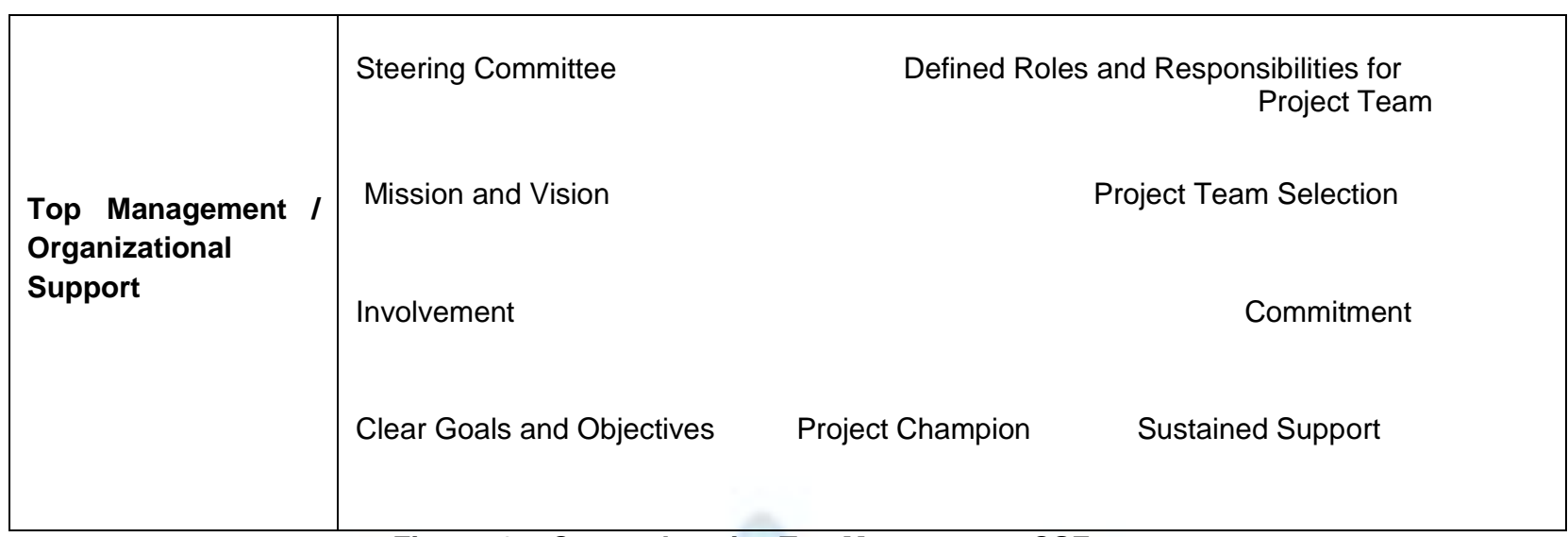

Figure 3 : Comprehensive Top Management CSFs

The statistical analysis for the Top Management shows that having clear goals and objectives followed by commitment, defined roles and responsibilities and project team selection were on the top considerations for the ERP implementers. Moreover, all the sub-factors are rated critical by the respondents making the Top Management CSF and all its related CSFs crucial for ERP implementers.

Table 1 : Survey results for Top Management CSFs

\begin{tabular}{|l|l|l|l|}
\hline \multicolumn{2}{|l|}{ Critical Success Factors } & Mean & Std. Dev. \\
\hline Serial No. & CSF Category & $\mathbf{4 . 8 5}$ & $\mathbf{0 . 3 6 6 3 4 8}$ \\
\hline Top Management /Organizational Support & $\mathbf{4 . 6 5}$ & $\mathbf{0 . 4 8 9 3 6}$ \\
\hline $\mathbf{1 .}$ & Clear Goals and Objectives & 4.6 & 0.502625 \\
\hline $\mathbf{2 .}$ & Commitment & 4.5 & 0.512989 \\
\hline $\mathbf{3 .}$ & Project Champion & 4.45 & 0.759155 \\
\hline $\mathbf{4 .}$ & Defined Roles and Responsibilities for the team & 4.35 & 0.67082 \\
\hline $\mathbf{5 .}$ & Project Team Selection & 4.3 & 0.571241 \\
\hline $\mathbf{6 .}$ & Steering Committee & 4.05 & 0.759155 \\
\hline $\mathbf{7 .}$ & Involvement & 4.05 & 0.998683 \\
\hline $\mathbf{8 .}$ & Sustained Support & Mission \& Vision & \\
\hline $\mathbf{9 .}$ & &
\end{tabular}

\subsubsection{Project Management}

The review studies (Tsai, Lee, Shen \& Yang, 1994; Somers \& Nelson , 2001 ; Ngai et al., 2008) had stressed on the terminology of effective project management terminology to encompass all the issues concerning this aspect. The survey however aimed to cover all minute aspects related to project management aspect starting from project planning to management to project review

Complexity, large resource commitment, and enterprise-wide scope of ERP projects make them an intricate exercise in planning and project management (Radding, 1999). Many ERP analysts have stressed the importance of project management and planning for successful implementation (Davenport, 2000). The ERP project plan serves as guide for the implementation and also establishes the expectations for how the project should be completed. An ERP project requires a cross-functional and multi-skilled implementation team because of its enterprise-wide scope (Davenport, 2000). The ERP project manager must have a clear vision and good communication to ensure everyone on the team knows exactly what the project is to accomplish, completing tasks within appropriate timings, adhering to budget constraints, producing deliverables as agreed to meet stakeholders' expectation. Another key area of project management is the competence of project team (Somers \& Nelson, 2001). Competence of project team members in terms of insight and focus will reduce implementation time, enhance project quality and help understand and explain new concepts and processes (Brown \& 
Vessy, 1999). The review studies have however (Nah et al., 2001; Somers \& Nelson, 2001; Umble et al., 2003; Ngai et al., 2007; Garcia-Sanchez \& Bernal, 2007; etc.) had stressed on the terminology of effective project management terminology to encompass all the issues concerning this aspect The survey further indicates that co-ordination and cooperation between functional groups poses a larger challenge as the new systems are based on a process view of the organization and necessitates ample cross-functional co-ordination. Project scope is rarely devised which results in gap between the user's requirement and implementation team. Thus, project scope and time for implementation are further essential requisites for effective Project Management. Finally, a tightly controlled project scope and time would reduce ERP implementation cost. (Gray \& Larson, 2000). All these project management CSFshave been rarely sieved clearly in the review literature to show their due importance.

\begin{tabular}{|l|lr|}
\hline $\begin{array}{l}\text { Project } \\
\text { Management }\end{array}$ & Project Planning & Effective Project Management \\
& Project Team Competence & Project Schedule \& Plans \\
& Interdepartmental Coordination & Scope of Implementation \\
& Interdepartmental Cooperation & Implementation Time \\
& & \\
\hline
\end{tabular}

Figure 4 : Comprehensive Project Management CSFs

Within Project Management CSF, having effective project management with stress on interdepartmental coordination and cooperation CSFs were specified. Again all the Project Management related CSFs were rated critical by the respondents making it a vital CSF to monitor and control.

Table 2: Survey results for Project Management CSFs

\begin{tabular}{|c|c|c|c|}
\hline \multicolumn{4}{|c|}{ Critical Success Factors } \\
\hline Serial No. & CSF Category & Mean & Std. Dev. \\
\hline \multicolumn{4}{|c|}{ Project Management Aspect } \\
\hline 1. & Effective Project Management & 4.65 & 0.48936 \\
\hline 2. & Interdepartmental Cooperation & 4.65 & 0.48936 \\
\hline 3. & Project Planning & 4.6 & 0.502625 \\
\hline 4. & Project Team Competence & 4.6 & 0.502625 \\
\hline 5. & Scope of Implementation & 4.6 & 0.502625 \\
\hline 6. & Implementation Time & 4.55 & 0.510418 \\
\hline 7. & Project Schedule \& Plans & 4.5 & 0.512989 \\
\hline 8. & Interdepartmental Coordination & 4.5 & 0.760886 \\
\hline
\end{tabular}

\subsubsection{Client/People Aspect}

The survey attempted to seek all people/client related issues under one platter. A comprehensive listing of people's CSF was elusive feature of the review studies .ERP implementation has been referred to as an "organization wide revolution" due to the large number of changes it brings to an organization (Bingi et al., 1999). Benjamin \& Levinson (1993) state that many organizations face problems in implementing advanced information technology projects because they put inadequate stress on the management of change brought about by the technology.

Involvement of employees reduces their resistance or fear of the new system (Mendel, 1999). Involved users are not only motivated to adapt to the new system but they also help identify and resolve potential issues early, thereby help improve implementation quality (Brown, 2001).

Training and updating employees on ERP is a major challenge as it is extremely complex and demanding. It is difficult for trainers or consultants to pass on the knowledge of ERP package to the employees in a short period of time. This knowledge transfer gets hard if the employees lack computer literacy or have computer phobia. In addition to being taught 
ERP technology, employee has to be taught their new responsibilities. Training teaches new skills leading to increased confidence and enthusiasm towards the new system. The key to training lies in balancing the needs of the current work and the new system (O'Leary, 2000).

As with any new technology, an ERP system must eventually and ultimately be integrated into a larger, more complex social and technological business organization and companies. This CSF had been widely reported in the cited models in terms of Change and Expectations Management (Nah et al. 2001; Somers \& Nelson 2001; Umble et al. 2003; Ngai et al 2007; Garcia-Sanchez \& Bernal, 2007). Realizing the best use of technology requires knowledge of not only the technology itself but also the organization and its people for whom the technology is implemented. Managing change is arguably one of the primary concerns of ERP implementation. Knowledge about managing change in an organization should be prioritized as implementing change without any prior planning or strategy in organizations will result in confusion and instability amongst employees (Chan, 1999; Motwani et.al, 2005). Training initiatives and education are usually an integral component of change management. The implementers feel that the organization should invest in the training and education of their employees so as to enhance their ERP skills and to ensure they are capable of understanding their business processes and functions. In effect, half of the ERP implementations have failed to achieve expected benefits as a result of misjudging the efforts involved in change management (Somers \& Nelson, 2001). In the absence of change management initiatives resulted in employees' confusion, instability and resistance.

Knowledge is considered as an enterprise's invisible assets. So far EIS such as ERP systems are developed and implemented mainly for managing physical assets of an enterprise. Due to the fact that both types of assets need to be properly managed, the integration of knowledge management and ERP becomes a strategic initiative for providing competitive advantages to enterprises.

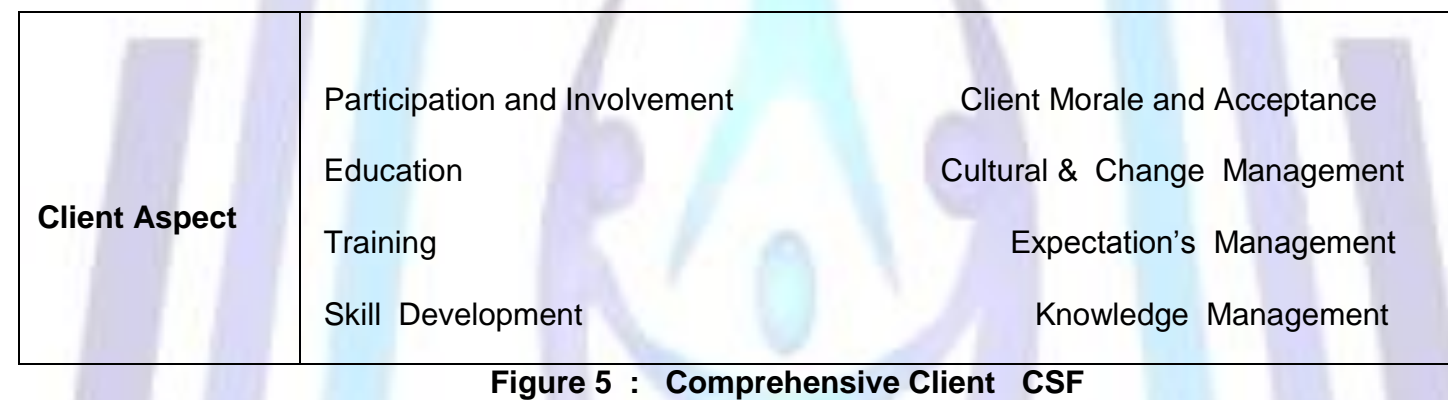

The survey indicates that participation and involvement of the client is required throughout the ERP project implementation phases. Further, client morale and acceptance of new system plays a vital role in establishing a healthy, people oriented enterprise system in the organization. Further, training could play a very supportive and crucial role in the whole success sequence. All remaining factors were also considered crucial and vital contributors to ERP success story.

Table 3 : Survey results for Client CSFs

\begin{tabular}{|l|l|l|l|}
\hline \multicolumn{2}{|l|}{ Critical Success Factors } & Mean & Std. Dev. \\
\hline CSF Category & \multicolumn{2}{l|}{} \\
\hline Client Aspect & $\mathbf{4 . 6 5}$ & $\mathbf{0 . 4 8 9 3 6}$ \\
\hline $\mathbf{1 .}$ & Participation and Involvement & $\mathbf{4 . 6 5}$ & $\mathbf{0 . 4 8 9 3 6}$ \\
\hline $\mathbf{2 .}$ & Client Morale and Acceptance & 4.65 & 0.587143 \\
\hline $\mathbf{3 .}$ & Training & 4.4 & 0.680557 \\
\hline $\mathbf{4 .}$ & Expectation's Management & 4.35 & 0.587143 \\
\hline $\mathbf{5 .}$ & Education & 4.25 & 0.55012 \\
\hline $\mathbf{6 .}$ & Skill Development & 4.25 & 0.638666 \\
\hline $\mathbf{7 .}$ & Change Management & 4.2 & 0.523148 \\
\hline $\mathbf{8 .}$ & Knowledge Management & & \\
\hline
\end{tabular}




\subsubsection{ERP Consultant}

Another important features covered in the survey were the subfactors related to consultant's role in the ERP project implementation. Literature review studies on CSFs studies have often covered only the aspects of use of consultant and the consultant cost.

Several studies have examined the factors that lead to a successful ERP implementation. Bingi et al. (1999) outline several critical factors, including the use of ERP consultants, for success in an ERP implementation. Garcia-Sanchez \& Bernal (2005) determine, through a review of the literature, that having external consultants is critical to ERP implementation success. ERP Consultant External consultants bring an outside perspective to the implementation team, which may contribute to the implementation's success ( Metrejean \& Stocks, 2011; Mische, 2000; Thong , Yap \& Raman ,1994; Wilcocks \& Skyes, 2000). Ifenedo \& Nahar (2006) showed that the use of quality external experts is critical for the success of ERP systems. The study also shows that the user of external experts is more important that even management's support of the ERP system.

Previous studies in their literature reviews suggest that the ERP implementation team should include a mix of consultants and internal personnel. Yap, Soh \& Raman (1999) found that for organizations that having effective consultants increased the likelihood of a successful ERP.

Ko, Kirch \& King (2005) examined the relationship between consultants and their clients. The authors found that it was important to create an interactive environment between consultants and client personnel so that that knowledge can flow freely between the two parties. Slater (1999) indicated that external consultants should be used because they bring an external and hopefully independent point of view to the implementation team. Slater (1999) suggested that using consultants may lead to getting things right the first time but does not make any full time promises.

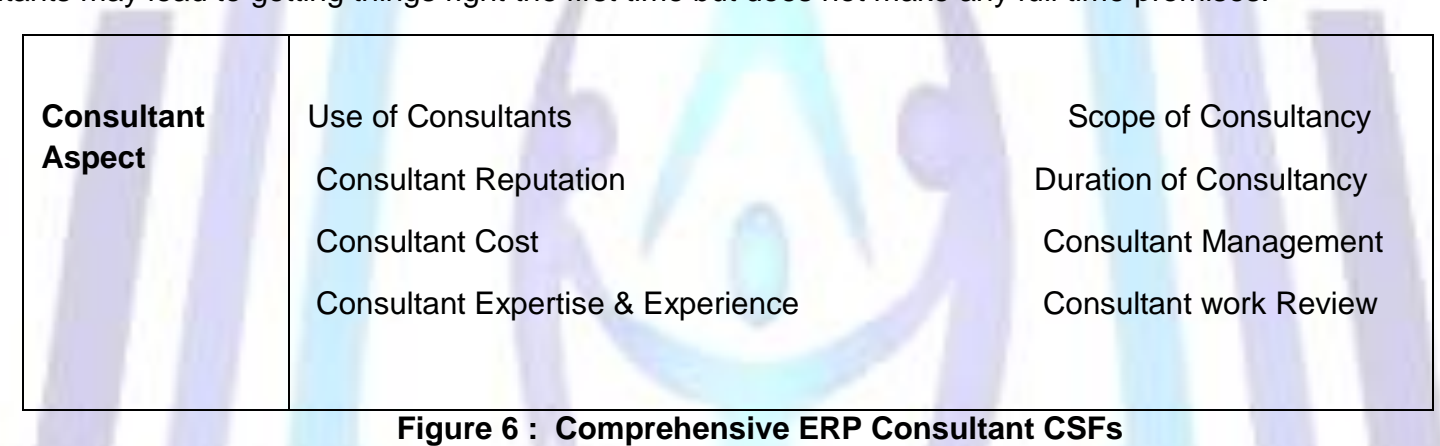

Yap et al. (1999) used three characteristics to associate the effectiveness of consultants with information system implementation success. These three characteristics were consultant experience, consultant capability, and consultant effectiveness during the feasibility study. Experience typically leads to capability. Thong et al. ( 1999) identified four variables to assess a consultant's performance during an information system implementation. These variables were consultant effectiveness in performing analysis of requirements of the business, consultant effectiveness in recommending the proper solution, consultant effectiveness in managing the implementation, and the relationship between the consultant and the other parties involved with the project. Mische (2000) proposed several characteristics that were desirable in information systems consultants. These characteristics include communication skills; the consultant's background, experience, and familiarity with the issues in the implementation; the ability to determine the organization's needs and expectations and assign personnel to meet those needs and expectations; personality and chemistry; objectivity; expertise with systems implementations; and commitment to quality.

Table 4 : Survey results for Client CSFs

\begin{tabular}{|c|c|c|c|}
\hline \multicolumn{4}{|c|}{ Critical Success Factors } \\
\hline \multicolumn{2}{|c|}{ CSF Category } & Mean & Std. Dev. \\
\hline \multicolumn{4}{|c|}{ ERP Consultant } \\
\hline 1. & Use of Consultants & 4.7 & 0.470162 \\
\hline 2. & Consultant Management & 4.45 & 0.510418 \\
\hline 3. & Consultant Work Review & 4.45 & 0.686333 \\
\hline 4. & Consultant Expertise \& Experience & 4.45 & 0.686333 \\
\hline
\end{tabular}




\begin{tabular}{|l|l|l|l|}
\hline 5. & Scope of Consultancy & 4.4 & 0.712103 \\
\hline 6. & Duration of Consultancy & 4.4 & 0.712103 \\
\hline 7. & Consultant Cost & 4.0 & 0.861951 \\
\hline 8. & Consultant Reputation & 4.0 & 0.861951 \\
\hline
\end{tabular}

The survey results show that use of consultants is recommended by the ERP survey respondents. The respondents feel that technical skills and knowledge, a commitment to producing quality work, and ability to manage the ERP implementation all essential attributes of a consultant, contribute to the effectiveness of ERP project implementation. Further, survey had bought into light the importance fixing scope and during of consultancy along with consultant management and review.

\subsubsection{ERP Vendor}

The survey findings indicate that selection of a suitable ERP vendor is a crucial CSF for consideration so as to ensure wide variety of support ranging from technical assistance to training. In addition, an organization can reduce the cost of implementation, gain multiple benefits from partnerships with the vendor, and use the vendor's customization tools. The review studies have literally sidestepped the mammoth side concerns attached to the vendor's CSF. Vendor CSF encompasses in itself the vendor's reputation, credibility, technical capability, consultancy services, and vendor's implementation approach along with vital aspects of education, training and support services. Further, vendor partnership, management and work review were also considered.

Bryce \& Bryce (1987) had stressed the importance of the vendor's reputation for reliability. Goldenberg (1991) also recommends that buyers explicitly consider 'vendor reputation'. Bernroider \& Koch ( 2001) have put forth the evidence that larger organizations put a higher value on 'market position of vendor', with $35 \%$ rating this factor as 'very important' as compared with $17 \%$ of small and medium companies who rated it as 'very important.'

The company must have a fair idea of the vendor's stake in the market. .A look at his background, previous experiences, and clientele will enable them to decide for a suitable vendor. His credibility will have a say on the fortune of ERP supposedly to be implemented in the company. It is very important to analyze the vendor's credibility with respect to the area of service where the company desires to implement ERP. Such an evaluation will add value and meaning in terms of making the decision of choosing the ERP vendor. At the same time, it is not advisable to go for the best vendor in the market as said earlier for his services might not be the apt one for the company.

ERP vendors use different hardware platforms, databases, and operation systems, and some ERP software is only compatible with some companies' databases and operation systems. Thus, companies should conduct a requirements analysis first to make sure what problems need to be solved and select ERP systems that best suit their requirements. Two main aspects should be taken into consideration when selecting software/hardware: (1) compatibility of the software/hardware with the company's needs; and (2) ease of customization.

A diligent project plan, listing realistic and achievable goals and milestones should be put in place by the vendor. The selected vendor's track record of ERP implementation in past could serve as the key to estimate the time required to implement the project of similar dimension. This is vital to overcome the "IT time lag" and for meeting the changing requirements. The service quality of implementation ensuring the degree of transparency and fitness of information flow plays a vital role in generating initial small steps towards managing users' expectations and demands. The vendor should intelligently select the transition methodology for replacing the legacy system with the new ERP system. The outcome of each implementation phase should be well documented and approved from both the parties-the implementation team and the steering committee. Besides the documented phase deliverables, function specific manuals, flow charts, written procedures and minutes of meetings should also be maintained.

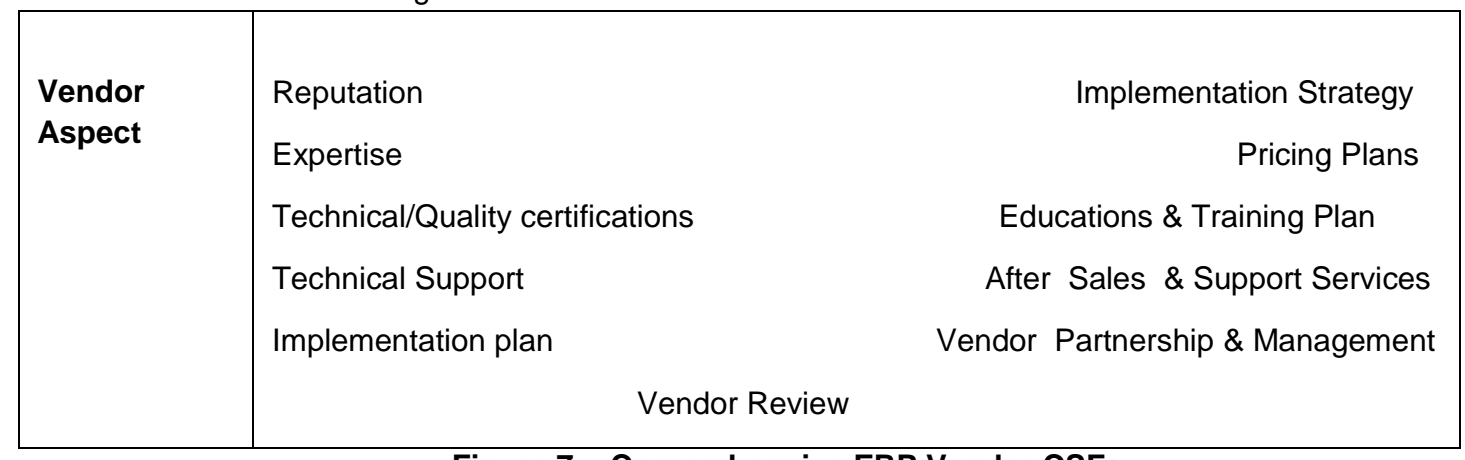

Figure 7 : Comprehensive ERP Vendor CSFs 
ERP systems are extremely complex and demand rigorous training. Training is regarded as important by both successful and unsuccessful projects. Importance on training was shared by all projects, but successful projects rated training quality higher and spent more on training. Without proper training, majority of the front-line workers will not be able to handle the demands of the new system Vendor detailed training schedules and efforts are critical to making a difference to the ERP experience of an organization.

Addition of new CSFs like Vendor partnership, Vendor Management and Vendor review are crucial in maintaining, monitoring and controlling vendor work.

The after sales service support services offered by the vendor and his commitment to it is very important in maintaining the post implemented ERP. The technical head count of vendor's support team, procedures followed for change requests, provision of different plans of support and maintenance, product upgrades inclusion in support plan, provision of $24^{\star} 7$ help desk support, web based portal support for submitting online queries, downloading fixes and product information, response time for queries/faults posted by users can make almost any ERP software a good fit.

Table 5 : Survey results for Vendor CSFs

\begin{tabular}{|c|c|c|c|}
\hline \multicolumn{4}{|c|}{ Critical Success Factors } \\
\hline \multicolumn{2}{|c|}{ CSF Category } & Mean & Std. Dev. \\
\hline \multicolumn{4}{|c|}{ ERP Vendor } \\
\hline 1. & Expertise & 4.75 & 0.444262 \\
\hline 2. & Vendor Partnership & 4.75 & 0.434162 \\
\hline 3. & Vendor Management & 4.75 & 0.444262 \\
\hline 4. & Implementation Strategy & 4.7 & 0.470162 \\
\hline 5. & After Sales \& Support Services & 4.55 & 0.759155 \\
\hline 6. & Technical support & 4.45 & 0.510418 \\
\hline 7. & Implementation Plan & 4.45 & 0.686333 \\
\hline 8. & Educations \& Training Plan & 4.4 & 0.598243 \\
\hline 9. & Vendor Review & 4.4 & 0.598243 \\
\hline 10. & Technical/Quality certifications & 4.35 & 0.74516 \\
\hline 11. & Reputation & 4.0 & 0.858395 \\
\hline 12. & Pricing Plans & 3.95 & 0.825578 \\
\hline
\end{tabular}

The survey findings also indicate that most of the vendor related issues are of critical importance to ERP implementers. Vendor's expertise and his implementation strategy drew the utmost importance from the implementers. After sales and support services, technical support and implementation plan were also rated very important by the implementers.

\section{CONCLUSION}

Stakeholders play critical role in successful implementation of ERP projects. They influence ERP success and are also affected by ERP deployments. Various ERP CSFs studies have been conducted earlier but our analysis shows that they lack completeness and also the proposed CSFs remain open for subjective assessment. The premise of the study summarized in this paper was to make a "complete" listing of stakeholder related CSFs while minimizing the subjectivity in their interpretation.

After review of existing literature and carrying out a survey of industry experts/practitioners and implementers, we have identified and listed 32-stakeholder related CSFs for ERP projects. An important contribution of the work is identification of 15-new stakeholder related CSFs which to the best of our knowledge were not listed by any of the prior ERP CSFs study. Importantly, survey respondents considered the newly identified CSFs as either important or very important and in few 
cases even as critical. The identified CSFs have also been logically grouped to facilitate their understanding and application in practical scenarios.

\section{REFERENCES}

[1] Akkermans, H., \& Van Helden, K. , "Vicious and Virtuous Cycles in ERP Implementation - A Case Study of Interrelations between Critical Success factors,", European Journal of Information Systems, 11(1), 2002, 35-46.

[2] Benjamin, R. I., \& Levinson, E. , "A Framework for Managing IT enabled Change," Sloan Management Review, 1993, 34 (4), 23-34.

[3] Bernroider, E., Koch, S. "ERP Selection Process in Midsize and Large Organizations," Business Process Management Journal, 7(3), 2001, 251-257.

[4] Bingi, P., Sharma, M, \& Godla, J., "Critical Issues Affecting an ERP Implementation," Information Systems Management, 16(3), 1999, 7-14.

[5] Botta-Genoulaz, V., Millet, P. \& Grabot, B., "A Survey on the Recent Literature on ERP Systems," Computers in Industry, 56, 2005, 510-522.

[6] Brown, J. ,"ERP Doomed by Poor Planning," Computing Canada, 2001, 27(3), 11

[7] Brown, C., \& Vessey, I. 1999. ERP implementation Approaches: Toward a Contingency Framework. In Proceeding of the 20th international conference on Information Systems, $411-416$.

[8] Bryce, M. and Bryce, T., "Make or Buy Software?", Journal of Systems Management, 38(8), 1987 , 6-11.

[9] Buyukozkan, G., Kahraman, C. \& Ruan, D., " A Fuzzy Multi-Criteria Decision Approach for Software Development Strategy Selection," International Journal of General Systems, 33(2-3), 2004, 259-280.

[10] Buyukozkan, G., Ertay, T., Kahraman, C. \& Ruan, D., "Determining the Importance Weights for the Design Requirements in the House of Quality using the Fuzzy Analytic Network Approach," International Journal of Intelligent Systems, 19(5), 2004, 443-461.

[11] Cantu, R., "A Framework for Implementing Enterprise Resource Planning Systems in Small Manufacturing Companies,” Master's Thesis, St. Mary's University, San Antonio, 1999.

[12] Chan, S.1999 .Architecture Choices for ERP Systems. In Proceedings of Americas Conference on International Systems (ACIS), Milwaukee, USA, August 13-15, 210-212.

[13] Chetcuti R. H. (2008). ERP Implementation: A Multi-Stakeholder Analysis of Critical Success Factors. WICT proceedings, 1-6.

[14] Davenport, T.H.," Putting the Enterprise into the Enterprise System," Harvard Business Review, (July-August), 76(4), 1998, 121-131.

[15] Dowlatshahi, S. "Strategic Success Factors in Enterprise Resource-Planning Design and Implementation: a case-study approach”, “International Journal of Production Research, 2005, 43(18), 3745-3771.

[16] Esteves, J. \& Pastor, J.,2000 . Towards the Unification of Critical Success Factors for ERP Implementation. In Proceedings of 10th Annual Business Information Technology (BIT) 2000 Conference, Manchester.

[17] Fok, L., Hartman, S., Fok, W. \& Jing Li, J., (2010).A Study of the Effectiveness of ERP Implementations in the US. . In Proceedings of Allied Academic International Conference. Academy of Strategic Management, 1-14.

[18] Garcia-Sanchez, N., \& Perez-Bernal, L. E., "Determination of Critical Success Factors in Implementing an ERP System: A Field Study in Mexican Enterprises", Information Technology for Development, 13(3), 2007, 293-309.

[19] Goldenberg, B. ,"Analyze key factors when choosing software,” Marketing News, 25(9), 1991, 23.

[20] Holland, C. and Light, B. ,"A critical success factors model for ERP implementation,” IEEE Software, 16(3) 1999, 30-36.

[21] Holland, C., Light, B. \& Gibson, N. 1999.A Critical Success Factors Model for Enterprise Resource Planning Implementation.In Proceedings of European Conference on Information Systems (ECIS), Copenhagen, Denmark,.273- 287. 
[22] Ifinedo, P., \& Nahar, N., 2006. Prioritization of Enterprise Resource Planning (ERP) Systems Success Measures: Viewpoints of Two Organizational Stakeholder Groups. In Proceedings of the 2006 ACM Symposium on Applied Computing, NY, USA, 1554-1560.

[23] KO, D. G., Kirsch L.J. \& King, W. R., "Antecedents of Knowledge Transfer from Consultants to Clients in Enterprise System Implementations," MIS Quarterly, 29(1), 2005, 59-84.

[24] Koch, C., "BPR and ERP: realising a vision of process with IT," Business Process Management Journal, 7(3), 2001, 258-265.

[25] Marnewick, C. \& Labuschagne, L. , "A Conceptual Model for Enterprise Resource Planning (ERP)," Information Management \& Computer Security, 2005, 13(2), 144 - 155.

[26] Mendel, B. "Overcoming ERP Project Hurdles," InfoWorld, 1999, July 19.

[27] Metrejean, E and Stocks H. M., "The role of consultants in the implementation of enterprise resource plans," Academy of Information and Management Sciences Journal, 14(1), 2011, 1-14.

[28] Mische, M. A., “Choosing a Systems Integrator," Enterprise Systems Integration, 2000, 873 - 885.

[29] Montazemi, A.R, Cameron, D.A \&. Gupta, K.M. , "An empirical study of factors affecting software package selection," Journal of Management Information Systems, 13(1), 1996, 89-105.

[30] Motwani, J., Subramanian, R. \& Gopalakrishna, P., "Critical Factors for Successful ERP Implementation: Exploratory findings from Four Case Studies," Computers in Industry, 2005, 56, 529-544.

[31] Nah, F. Lau, J., \& Kuang, J., "Critical factors for Successful Implementation of Enterprise Systems," Business Process Management Journal, 7(3), 2001, 285-296

[32] Ng, C., Gable, G. \& Chan, T, 2003. An ERP Maintenance Mode," . In Proceedings of 36th Hawaii International Conference on System Sciences, IEEE Big Island, USA:

[33] Ngai, E., Law, C. \& Wat, F., "Examining the critical success factors in the adoption of enterprise resource planning," Computers in industry, 57, 2008, 548-564.

[34] O'Leary, D., "Enterprise Resource Planning Systems - Systems, Life Cycle, Electronic Commerce and Risk. The Cambridge University Press, Cambridge, United Kingdoms, 2000.

[35] Plant, R. and Willcocks, L., "Critical Success Factors in International ERP Implementations: A Case Research Approach," The Journal of Computer Information Systems, 2005, 47 (3), 60-71.

[36] Radding, A.,"ERP: More than an Application,” Information Week, 1999,728, 1-4.

[37] Rockart, J., "Chief Executives Define their Own Data Needs," Harvard Business Review, 1979, March-April, 81-93.

[38] Shah H. I., Khan Z. A. \& Bokhari, H.R., "Exploring the Impediments of Successful ERP Implementation: A Case Study in a Public Organization," International Journal of Business and Social Science, 2(22), 2011, 289 -296.

[39] Sheu, C., Chae, B \& Yang, C. "National Differences and ERP implementation: Issues and Challenges," Omega, 32, 2004, 361-371.

[40] Slater, D. "An ERP Package for You....and You... and You...and Even You," CIO, 1999, 12 (9), 31 - 36.

[41] Somers, T.M., \& Nelson, K., 2001. The Impact of Critical Success Factors across the Stages of Enterprise Resource Planning Implementations. In Proceedings of the 34th Hawaii International Conference on Systems Sciences, 8, IEEE Computer Society, Washington, DC, USA.

[42] Sumner, M. , 2006. Critical Success Factors in ERP implementations: Five years later. In Proceedings of Americas Conference on Information Systems (ACIS), Acapulco, México, August 4-6, 2491-2500.

[43] Sun, A., Yazdani, A. \& Overend, J., "Achievement Assessment for Enterprise Resource Planning (ERP) System Implementations based on Critical Success Factors (CSFs)," International Journal of Production and Economics, $98,2005,189-203$.

[44] Thong, J. Y. L., C. S. Yap, \&. Raman. K. S., "Engagement of External Expertise in Information Systems Implementation," Journal of Management Information Systems, 11(2), 1994, 209 - 232. 
[45] Tsai, W., Lee, P., Shen, Y \& Yang, C., 2009. The Relationship between ERP Software Selection Criteria and ERP Success. In Proceedings of 2009 IEEE International Conference on Industrial Engineering and Engineering Management, 2222-2226.

[46] Umble, E., Haft, R. \& Umble, M., "Enterprise Resource Planning: Implementation Procedures and Critical Success Factors," European Journal of Operational Research, 2003,146, 241 - 257.

[47] Willcocks, L., and Skyes, R. (2000), "The role of the CIO and IT Function in ERP", Communications of the ACM, 43(4), 2000, 32-38.

[48] Welti, N. Successful SAP R/3 Implementation - Practical Management of ERP Projects. Harlow, Essex, England: Addison Wesley Longman Limited.1999.

[49] Yap, C. S., Soh, C. P. P., \& Raman, K. S. "Information Systems Success Factors in Small Business," International. Journal of Management Science, 20, 1999, 597-609.

[50] Zhang, L., Lee M., Zhang, Z. \& Banerjee, P., 2002.Critical success factors of Enterprise Resource planning systems implementation success in China. . In Proceedings of 36th Hawaii International Conference on System Sciences, IEEE, USA,. 236-245.

\section{AUTHOR BIOGRAPHIES}

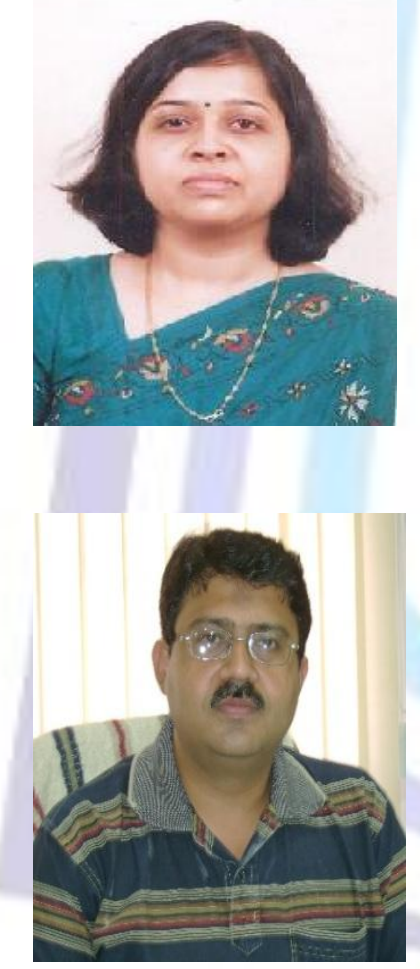

Rekha Gupta is an Associate Professor of Information Technology at Lal Bahadur Shastri Institute of Management, Delhi, India having 12 years of teaching and research experience. She is an M. Tech. from I.E.T.E and M.S(Software Systems) from BITS, Pilani, India. Her key research areas are IT implementation issues, ERP critical success factors and Selection Models.

S. Kazim Naqvi is Additional Director, ICT at FTK-Center For Information technology, Jamia Millia Islamia (A Central University), India. Previously, he has worked on several other academic as well as teaching positions in the University. He received his Ph.D. in Computer Science from JMI University, Delhi, India. He holds M.S. (Software Systems) from BITS Pilani, India. He possesses 15 years of experience in teaching and also in areas of ICT management including ERP development and implementation, Enterprise Network Management etc. His research interests include Information Systems, Talent Identification Models, Wireless networks. 


\section{APPENDIX A}

\section{QUESTIONNAIRE FOR ASSESSMENT OF}

\section{IMPACT OF CRITICAL SUCCESS FACTORS ON SUCCESS OF ERP PROJECTS}

This questionnaire solicits opinions from the ERP Experts, Consultants, Vendors and implementers for determining the impact of Critical Success Factors (CSFs) on success of ERP software system in organizations from stakeholders' perspective. The success factors used in the questionnaire are based on research study publication in 1999 by Cantu, R. (1) with minor modifications. Each broad Critical Success Factor is further categorized into sub-factors for deeper understanding of their individual contribution to the impact made.

A glossary of the technical terms used in the questionnaire is appended at the end of the document explaining the interpretation of terms as understood by the designer.

Section 1: Demographic Information

$1.1 \quad$ Name:.

1.2. Designation:

1.3 Company Address

1.4. Phone/Mobile No

1.5 e-mail

Section 2: $\quad$ ERP Product Specification

Section 3: $\quad$ ERP CSF Evaluation (PI. see glossary for interpretation of the terms used)

Based on your experiences and expertise in ERP, system rate the importance of the following Critical Success Factors on a 5 point scale:

( 1 = Unimportant 2 = slightly important $3=$ Important 4 = Very important 5 = Critical)

For each of the following CSF criteria, please encircle or tick one option to indicate your assessment of the importance of the CSF

\section{Product's Overall Success Criteria}

Top Management/ Organizational 1 Support

Project Management

12

Client Aspect

12

Consultant Aspect

Vendor Aspect

Please specify any other overall

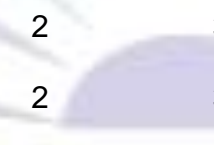

23

3

3

3

3
4

4

4

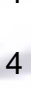

5

5

5

5

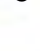

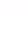




\begin{tabular}{|c|c|c|c|c|}
\hline Clear Goals and Objectives & 1 & 2 & 3 & 4 \\
\hline Defined Roles and Responsibility for the Project Team & 1 & 2 & 3 & 4 \\
\hline Project Team Selection & 1 & 2 & 3 & 4 \\
\hline Involvement & 1 & 2 & 3 & 4 \\
\hline Commitment & 1 & 2 & 3 & 4 \\
\hline Sustained Support & 1 & 2 & 3 & 4 \\
\hline
\end{tabular}

Please specify any other CSF related to "Top Management/Organizational Support" which is not covered above.

\section{$2 \quad$ Project Management}

Project Planning

Project Team Competence

Project Champion

Effective Project Management

Project Schedule \& Plans

Participation \& Involvement

Interdepartmental Co-ordination

Interdepartmental Cooperation

Scope of implementation

Implementation Time

tion

$\begin{array}{lll}1 & 2 \\ 1 & 2 \\ 1 & 2 \\ 1 & 2 \\ 1 & 2 \\ 1 & 2 \\ 1 & 2 \\ 1 & 2 \\ 1 & 2 \\ 1 & 2\end{array}$

$\begin{array}{lll}3 & 4 & 5 \\ 3 & 4 & 5 \\ 3 & 4 & 5 \\ 3 & 4 & 5 \\ 3 & 4 & 5 \\ 3 & 4 & 5 \\ 3 & 4 & 5 \\ 3 & 4 & 5 \\ 3 & 4 & 5 \\ 3 & 4 & 5\end{array}$

Please specify, any other CSF related to "Project Management" which is not covered above.

\section{Client Aspects}

Participation \& Involvement

Client Morale \& Acceptance

e

Education

(n)

Training

Skill Development

Knowledge Management

Change Management

Expectation's Management

$\begin{array}{lllll}1 & 2 & 3 & 4 & 5 \\ 1 & 2 & 3 & 4 & 5 \\ 1 & 2 & 3 & 4 & 5 \\ 1 & 2 & 3 & 4 & 5 \\ 1 & 2 & 3 & 4 & 5 \\ 1 & 2 & 3 & 4 & 5\end{array}$

Please specify any other CSF related to "Client Aspects" which is not covered above. 


\section{Vendor Selection}

Reputation

Expertise

Technical/quality certifications

Technical Support

Vendor Partnership

Vendor Management

Implementation Strategy

Pricing Plans

Implementation plan

Education \& Training Plan

After Sales \& Support Services

Vendor Review

$\begin{array}{lllll}1 & 2 & 3 & 4 & 5 \\ 1 & 2 & 3 & 4 & 5 \\ 1 & 2 & 3 & 4 & 5 \\ 1 & 2 & 3 & 4 & 5 \\ 1 & 2 & 3 & 4 & 5 \\ 1 & 2 & 3 & 4 & 5 \\ 1 & 2 & 3 & 4 & 5 \\ 1 & 2 & 3 & 4 & 5 \\ 1 & 2 & 3 & 4 & 5 \\ 1 & 2 & 3 & 4 & 5 \\ 1 & 2 & 3 & 4 & 5 \\ 1 & 2 & 3 & 4 & 5\end{array}$

Please specify any other CSF related to "Process Aspects" which is not covered above.

\section{Consultant Related}

Use of Consultant

Consultant Reputation

Consultant Experience \& Expertise

Consultant Management

Scope of Consultancy

Duration of Consultancy

Consultancy Cost

Consultant work Review

Please specify, any other CSF related to "Consultant aspects" which is not covered above 


\section{APPENDIX B : \\ GLOSSARY OF TERMS}

\section{Top Management Aspect}

- Steering Committee: The committee is responsible for understanding all important project issues and making appropriate decisions to keep the project on track, gathering the updated action items status, communicating steering committee decisions, and ensuring that decisions are carried out.

- Mission and Vision: The organization mission and vision statement should support the ERP implementation process.

- Involvement: Top Management should provide a continual support in terms of its interest, engagement and involvement of organization users towards ERP implementation.

- Project Champion: any individual who made a decisive contribution to the innovation by actively and enthusiastically promoting its progress through critical stages in order to obtain resources and/or active support from top management

- Clear goals and Objectives: Top management should clearly specify the aims, objectives and expected returns from the software implementation.

- Project Team Selection: Top management should carefully select personnel who can handle and deliver for the ERP implementation team

- Defined Roles and Responsibilities for the Project team: The role of each team member as an individual and in the team should be precisely defined and responsibilities along roles have to be articulately carved out.

- Commitment: The top management should have a strong commitment for the ERP project right from inception to its final implementation

- Sustained Support: The top level should show committed stand in spite of top management personnel changes, financial expenses, patience towards managing expectations and change management.

\section{Project Management Aspect}

- Project Planning: This planning is about how to complete the ERP project within a certain timeframe, usually with defined stages, and with designated resources

- Project Team Competence: Refers to capabilities of team implementing the ERP project.

- Effective Project Management: The project team should stick to scheduled timelines, budget guidelines and for smoother transition

- Project Schedule and Plans: The primary uses of the project plan are to document planning assumptions and decisions, facilitate communication among stakeholders, and document approved scope, cost, and schedule baselines. A schedule is a listing of a project's milestones, activities, and deliverables, usually with intended start and finish dates. Those items are often estimated in terms of resource allocation, budget and duration, linked by dependencies and scheduled events

- Interdepartmental Coordination and Co-operation : Refers to synchronization and co-operation required across and within areas , irrespective of functionalities--

- Scope of Implementation: The outcomes and deliverables should be well defined and articulated both to the vendor and the project management team.

- Implementation Time: refers to time required for implementation depending on business size, modules and extent of customization.

- Dedicated Resources: hardware and software resources dedicated to ERP project

- BPC and Software Configuration: Business Process Customization is the act of defining the whole work-flow from the start to closure in software. Configuration is the task of tracking and controlling changes in the software

- Minimal customization: refers to making minimal changes in existing hardware and software 
- Software Development \& Testing: is the development of a software product. The term "software development" may be used to refer to the activity of computer programming, which is the process of writing and maintaining the source code, but in a broader sense of the term it includes all that is involved between the conception of the desired software through to the final manifestation of the software, ideally in a planned and structured process. Software testing is an investigation conducted

- To provide stakeholders with information about the quality of the product or service under test.

\section{Client Terms}

- $\quad$ Participation \& Involvement: ERP implementation should have active and voluntary participation

- $\quad$ Client Morale and Acceptance: refers to morale of people in implementing organization and their readiness towards accepting the implementation.

- Education: People should be aware of ERP implementation and should have mind-set orientation towards acceptance of the software

- Training: User's should be given sufficient training to learn the usage of the software, be aware of its capabilities and its limitations.

- $\quad$ Skill Development: User's should have a skill orientation development from file based process management to software based process management.

- Knowledge, Change and Expectation's Management: Does the software Vendor and implementing organization have provision for managing knowledge, Change and Expectation's Management.

\section{Consultant Aspect}

- Use of Consultants: refers to engaging external consultants for ERP project consultants(both business and process based)

- Consultant Cost: Cost incurred in utilizing the services of an expert/consultant for ERP implementation.

- Consultant Experience \& Expertise: refers to the experience and expertise of the consultant in a domain area

- Consultant reputation: To be visualized in terms of reliability of vendor

- Consultant Management: To be visualized in terms of establish the number of hours budgeted for each week for each ERP consultant based on the major project activities planned each week and the consultant's responsibilities.

- Scope of Consultancy: refers to fixing the responsibility of the consultant in the ERP software scope.

- Duration of Consultancy: refers to the no. of hours the consultant spends on the project as the project implementation grows.

- Consultant Work Review: Periodically mapping consultants deliverables to the work defined in the scope charter.

\section{Vendor Aspect}

- Reputation: To be visualized in terms of reliability of vendor

- $\quad$ Expertise: Refers to the specialization domain area of working

- Credibility: To be measured by looking at his background, previous experience, clientele, area of domain specialization.

- Technical/quality support capability: Terms of hardware /software compatibility of ERP with existing company's technical capability and quality standards.

- $\quad$ Consulting Performance: Vendor's consultancy services post purchase of the ERP software.

- Implementation strategy: Vendor's track record of earlier implementation, service quality, transition plan and documentation plan.

- Implementation plan: refers to phase wise plan of implementation with team requirements, members with due 
responsibilities inclusive of design aspects and project assumptions.

- Education \& Training :Vendor's training schedule and Knowledge transfer strategy

- Vendor Management: Tracking vendor scope of work as per predefined charter with active involvement and participation.

- Support Services: Vendor's after sales service support including project inclusion plans, support plans etc.

- Vendor Management: refers to the implementation services contract with the vendor and regular monitoring of it

- Vendor Review: refers to performance measurement of vendor's work on a performance matrix.

\section{APPENDIX C}

Below, we summarize the categorized CSFs for the stakeholders as presented in the questionnaire survey and also show their coverage in terms of past literature review studies.

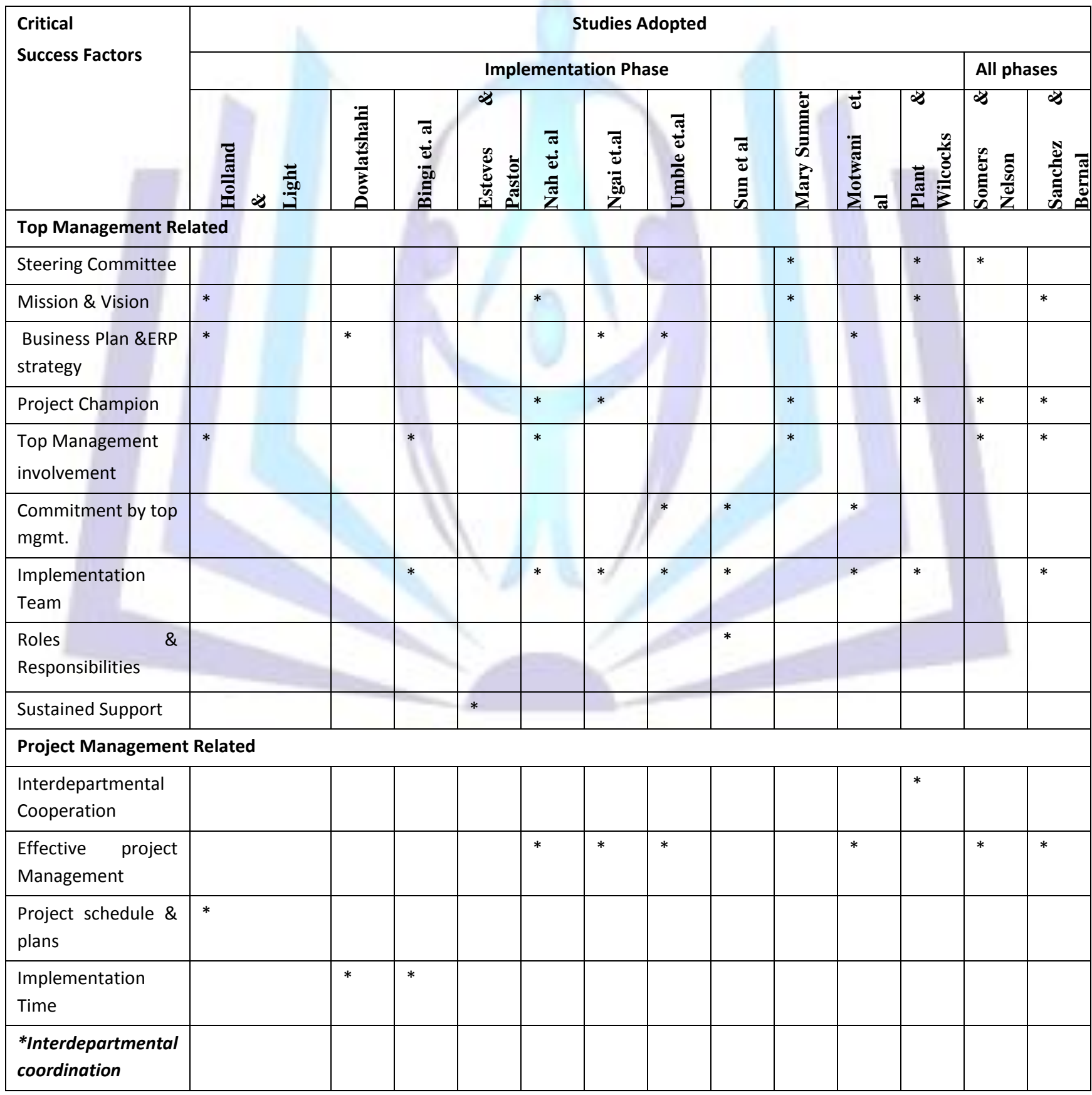




\begin{tabular}{|c|c|c|c|c|c|c|c|c|c|c|c|c|c|}
\hline $\begin{array}{l}\text { *Scope of } \\
\text { Implementation }\end{array}$ & & & & & & & & & & & & & \\
\hline Client Related & & & & & & & & & & & & & \\
\hline Client Involvement & & & & & & & & & & & & & * \\
\hline Client consultation & * & & & & & & & & & & & & \\
\hline $\begin{array}{l}\text { Education and } \\
\text { training }\end{array}$ & & * & * & & & & * & * & & & * & * & $*$ \\
\hline Personnel & * & & & & & & & & & & & & \\
\hline Client Morale & & & * & & & & & & & & & & \\
\hline Client acceptance & * & & & & & & & & & & & & \\
\hline $\begin{array}{l}\text { Cult \& Change } \\
\text { Mgmt. }\end{array}$ & & & & & $*$ & * & $*$ & & * & * & * & & * \\
\hline $\begin{array}{l}\text { Expectations } \\
\text { Management }\end{array}$ & & & & & & & & & & & $*$ & * & \\
\hline Skill development & & & & cer & & & & * & & & & & \\
\hline $\begin{array}{l}\text { Knowledge } \\
\text { management }\end{array}$ & & & & & & & & * & & & & & \\
\hline Consultant Aspect & & & & & & & & & & & & & \\
\hline $\begin{array}{l}\text { Having external } \\
\text { Consultants }\end{array}$ & & & * & * & & * & & & $*$ & & * & * & $*$ \\
\hline $\begin{array}{l}\text { Consultant } \\
\text { reputation }\end{array}$ & & & * & res & $\theta$ & 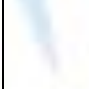 & & & & & & & \\
\hline $\begin{array}{l}\text { Consultant } \\
\text { Expertise } \\
\text { Experience }\end{array}$ & & & * & & 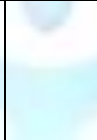 & 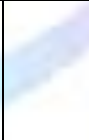 & & & & & & * & \\
\hline Consultant Cost & & & * & & & & & & * & & & * & * \\
\hline $\begin{array}{lr}* & \text { Scope } \\
\text { Consultancy }\end{array}$ & & & & & & & & & 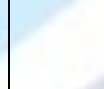 & & & 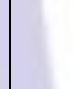 & \\
\hline $\begin{array}{l}\text { * Duration of } \\
\text { Consultancy }\end{array}$ & & & & & & & & & & & & & \\
\hline $\begin{array}{l}\text { Consultant } \\
\text { Management }\end{array}$ & & & * & & & & & & & & & & \\
\hline $\begin{array}{l}{ }^{*} \text { Consultant Work } \\
\text { Review }\end{array}$ & & & te & & & & tont & & & & & & \\
\hline Vendor Related & & & & & & & & & & & & & \\
\hline $\begin{array}{l}\text { *Vendor } \\
\text { Reputation }\end{array}$ & & & & & & & & & & & & & \\
\hline${ }^{*}$ Expertise & & & & & & & & & & & & & \\
\hline $\begin{array}{l}{ }^{*} \text { Technical } \\
\text { certifications }\end{array}$ & & & & & & & & & & & & & \\
\hline${ }^{*}$ Technical Support & & & & & & & & & & & & & \\
\hline $\begin{array}{l}\text { Vendor/customer } \\
\text { partnerships }\end{array}$ & & & * & & & * & & & & & * & * & \\
\hline $\begin{array}{l}\text { Use of vendor's } \\
\text { development tools }\end{array}$ & & & & & & & & & & & $*$ & * & \\
\hline
\end{tabular}




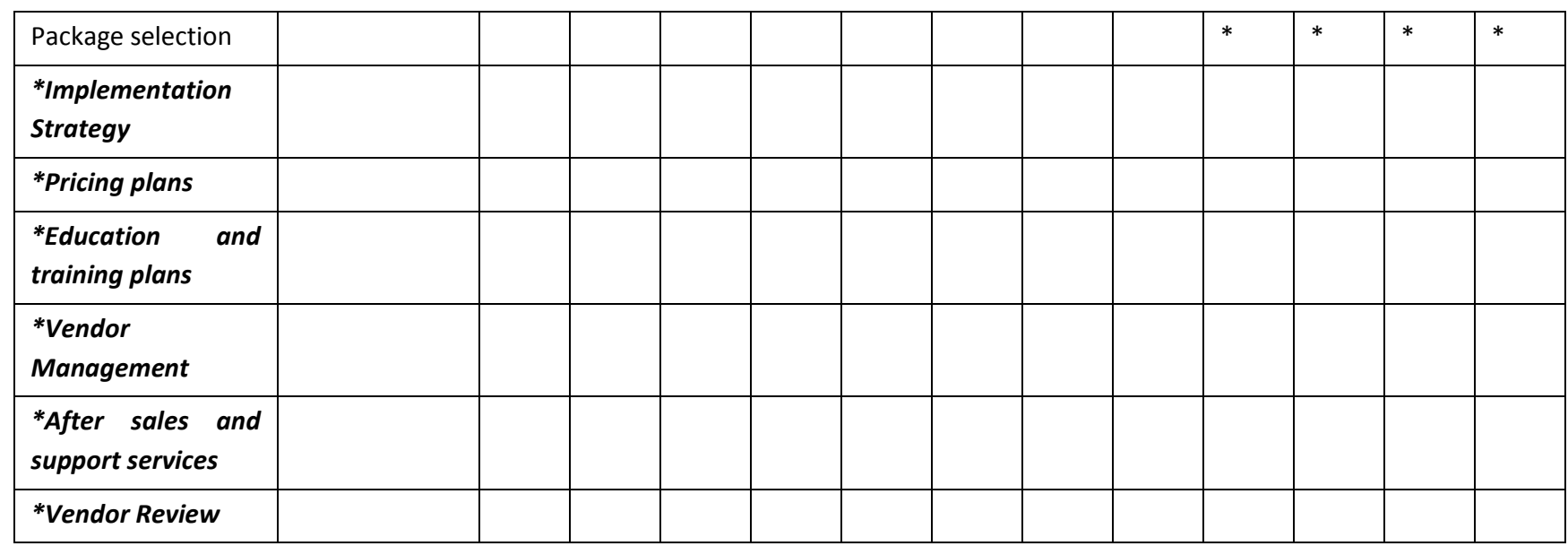

*additional CSFs listed as a result of questionnaire survey

Literature review CSFs along with Survey new CSFs 